\title{
Cybister tripunctatus africanus (Castelnau, 1834) (Coleoptera Dytiscidae): first record for Lampedusa Island (Pelagie Islands, Sicily Channel)
}

\author{
Elena Prazzi, Giuseppe Maraventano,Vincenzo Billeci \& Gerry Sorrentino
}

Legambiente Sicilia, Ente Gestore Riserva Naturale Isola di Lampedusa, Via Vittorio Emanuele 25, 92031 Lampedusa, Italy; e-mail: lampedusa@legambienteriserve.it

\begin{abstract}
The authors report the first record of the Dytiscidae Cybister tripunctatus africanus (Castelnau, 1834) for Lampedusa Island (Sicily Channel, Italy), which also represents the first finding of an acquatic insect belonging to Coleoptera Dytiscidae in this island.
\end{abstract}

KEY WORDS Coleoptera; Dytiscidae; Lampedusa.

Received 12.01.2020; accepted 10.02.2020; published online 22.02.2020

\section{INTRODUCTION}

Cybister tripunctatus africanus (Castelnau, 1834) (Coleoptera Dytiscidae) is a species with southern-Mediterranean-Ethiopian spread, known in Italy in Friuli Venezia Giulia, Lazio, southern regions, Sicily and Sardinia (Franciscolo, 1979; Angelini, 1984).

Aquatic and predatory species, even at the larval stage, it lives in retro-dune ponds, mouths and residual pools of small streams, preferably on muddy substrates (Franciscolo, 1979). Cybister tripunctatus africanus is also an excellent flyer.

In Sicily, it is a quite widespread species, at medium and low altitudes, in natural and artificial waters (Sparacio, 1995). Ragusa (1887) already indicated it as: “... comunissima specialmente nel lago di Lentini [very common especially in Lake Lentini] ...".

Also present in Tunisia (Touaylia et al., 2010), this species is not known in Lampedusa where, according to Romano (1995), the almost total lack of natural humid environments did not allow the es- tablishment of a permanent population of Ditiscid insects.

\section{DISCUSSION AND CONCLUSIONS}

On September 3rd, 2019 an adult female specimen of C. tripunctatus africanus was found in Lampedusa, in Contrada Piddu. The insect was inside the room of a hotel, overlooking the property's garden.

The discovery of this unique specimen suggests that the insect has flown over the island, presumably transported by favourable winds from North Africa. In fact, it is not the first time that in Lampedusa there have been reports of insects that have flown or been carried by the wind as for Campalita algirica (Géhin, 1885) and C. olivieri (Dejean, 1831) (Casale et al., 1982 and Vigna Taglianti, 1995; see also for Sicily: Monastra, 1984; Aliquò \& Castelli, 1991; Sparacio, 2003) or by active immigration, as in the case of the Orthoptera Brachytrupes megacephalus (Lefebvre, 1827) and Schistocerca gregaria (Forskål, 1775) (Prazzi et al., 2014). 


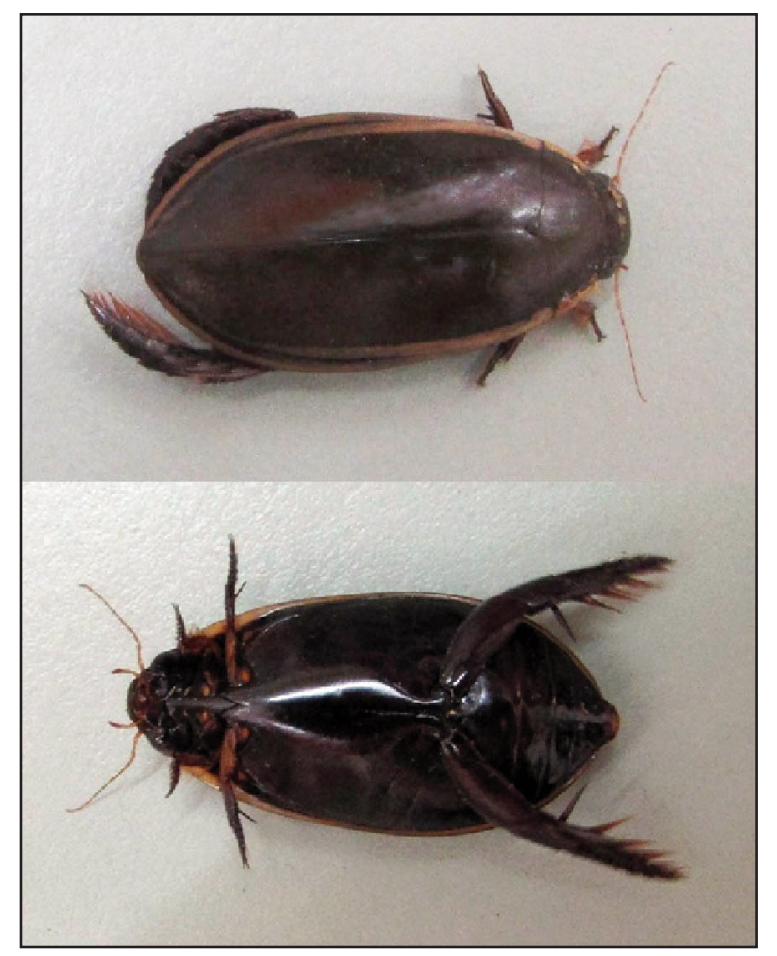

Figure 1. Cybister tripunctatus africanus from Lampedusa Island, Italy.

Following this finding, it is considered appropriate to deepen the research of further specimens of Cybister tripunctatus africanus to evaluate whether a stabler settlement of this species is present in Lampedusa.

In particular, the research of this species, but also of other aquatic Coleoptera, will be carried out in correspondence with reservoirs, artificial tanks and in the temporary pools that form inside cavities of karst rocks used in Lampedusa as reproductive sites by the African green toad, Bufo boulengeri Lataste, 1879 (Lo Valvo et al., 2017).

\section{REFERENCES}

Aliquò V. \& Castelli V.D., 1991. Nuovi dati sui Coleotteri
Cicindelidi e Carabidi del Trapanese. Libera Università Trapani, 10: 5-66.

Angelini F., 1984. Catalogo dei Coleóptera Haliplidae, Hygrobiidae, Dytiscidae e Gyrinidae d'Italia. Memorie della Società entomologica italiana, 61 A: 45126.

Casale A., Sturani M. \& Vigna Taglianti A., 1982. Coleoptera Carabidae. I. Introduzione, Paussinae, Carabinae. Fauna d'Italia, 18. Edizioni Calderini, Bologna, 12+ 499 pp.

Franciscolo M.E., 1979. Coleoptera: Haliplidae, Hygrobiidae, Gyrinidae, Dytiscidae (Fauna d'Italia, 14). Calderini, Bologna, 804 pp.

Lo Valvo M., Faraone F.P., Giacalone G. \& Lillo F., 2017. Fauna di Sicilia. Anfibi. Monografie Naturalistiche, 5. Edizioni Danaus, Palermo, 136 pp.

Monastra A., 1984. Secondo ritrovamento di Campalita algiricum Géhin in Sicilia (Coleoptera, Carabidae). Il Naturalista siciliano, 8: 63.

Prazzi E., Billeci V., Maraventano G., Sanguedolce F. \& Sorrentino G., 2014. Presenza di Brachytrupes megacephalus (Lefèbvre, 1827) (Orthoptera Gryllidae) e Schistocerca gregaria (Forskål, 1775) (Orthoptera Acrididae) nell'Isola di Lampedusa (Pelagie, Canale di Sicilia). Il Naturalista siciliano, 38: 121-123.

Ragusa E., 1887. Catalogo ragionato dei Coleotteri di Sicilia. Il Naturalista siciliano, 7: 41-43.

Romano M., 1995. Coleoptera Dytiscidae. In: Massa B. (ed.), Arthropoda di Lampedusa, Linosa e Pantelleria (Canale di Sicilia, Mar Mediterraneo). Il Naturalista siciliano, 19 (Suppl.): 423-426.

Sparacio I., 1995. Coleotteri di Sicilia. I. L'Epos Società Editrice, Palermo, 238 pp.

Sparacio I., 2003. Ritrovamento in Sicilia di Campalita olivieri (Dejean, 1831) (Coleoptera Carabidae). Il Naturalista siciliano, 27: 209-211.

Touaylia S., Garrido J., Béjaoui M. \& Boumaiza M., 2010. A Contribution to the Study of the Aquatic Adephaga (Coleoptera: Dytiscidae, Gyrinidae, Haliplidae, Noteridae, Paelobhdae) from Northern Tunisia. The Coleopterists Bulletin, 64: 53-72 (1 March 2010). https://doi.org/10.1649/0010-065X64.1 .53

Vigna Taglianti A., 1995. Coleoptera Carabidae. In: Massa B. (Ed.), Arthropoda di Lampedusa, Linosa e Pantelleria (Canale di Sicilia, Mar Mediterraneo). Il Naturalista siciliano, 19 (Suppl.): 357-421. 